\title{
The Risk of Opioid Misuse in a College Population
}

\author{
James Gilbert \\ The University of West Alabama \\ UWA Station 59 \\ Livingston, AL 35470 \\ 205-652-5466
}

\begin{abstract}
Objectives: To evaluate the potential risk for opioid misuse in a limited sample of college students utilizing the Screener and Opioid Assessment for Patients with Pain-Revised (SOAPP-R). This study also looks at the impact of unrealistic expectation on increased risk for misuse.

Method: The Screener and Opioid Assessment for Patients with Pain-Revised (SOAPP-R) was incorporated as part of a broader questionnaire including specific questions pertaining to the use of both opioid and over-the-counter pain medications. This questionnaire was distributed by internet list-serve to both graduates and undergraduates in a rural public university.

Results: There were 134 responders (female-110, Male-11, 2-deferred) who completed the questionnaire. Of those responding, $12.5 \%$ fell into the High-Risk category, $44.12 \%$ fall into the Moderate-Risk category, and $42.53 \%$ fell into the Low-Risk category. Of those individuals who completed the questionnaire, 57.2\% expected to become pain free after taking some form of pain medication. Combining Moderate and High Risk categories demonstrated a clinically significant correlation between expectation to become pain free and increased risk for misuse. Consideration of these categories individually failed to reach clinical significance.

Conclusions: In this sample, greater than half the college students participating had a moderate to high risk for the misuse of pain medications as measured by the SOAPP-R.

Summary: This study demonstrated an increased risk opioid abuse in a limited population of college students. The primary limitation in this case was the limited sample size. Future research should include a greater number of participants that are more evenly distributed relative to gender. Future research should also identify those who engage in recreational use of opioids.
\end{abstract}

Keywords: Opioids, At Risk, Misuse, College Population

For most young adults, attending college is a time of self-exploration and development, eventually leading to the goal of living independently. Learning to make independent decisions ranges from personal finance to personal health. Recent studies suggest that that the risk of Nonmedical use of Opioid Medications (NMUOM) is a significant risk for individuals of college age (Johnson, Miech, O’Malley, Bachman, Schelenberg \&Patrick (2019); Malone (2017). This study will use the Screener and Opioid Assessment for Patients with Pain (SOAP-R) to explore the risk for opioid misuse in the college population. For some individuals, an unrealistic expectation for pain relief may lead to overuse or misuse of both prescribed and non-prescribed pain medication. The overuse of medication has become a national issue. A secondary consideration will explore the impact of this unrealistic expectation for pain relief in potential misuse of pain relieving medications. This will open the door for future research regarding the incidence of pseudoaddictive behaviors in this population.

\section{Literature Review}

A review of available literature supports the concept of recreational misuse of prescribed medications in college students. The American Journal of Preventive Medicine relates that Drug Poisoning is now the leading cause of injury deaths in the US, increasing more than 300 percent over the last three decades. Almost 90-percent of poisoning deaths can be attributed to the legal or illegal use of prescription medications (AJPM Nov. 2013).

To more specifically consider the prevalence of the misuse of opioid pain medications, McCabe (2007) published a study purporting that students who took opioids for other than pain relief had a much greater risk of experiencing three or more drug related problems. He later presented further research reporting that students who take prescription medication for non-medical symptoms are five-times more likely to develop a drug abuse or substance dependence problem (McCabe, 2008). Fifty percent of college students are offered a prescription medication for non-medical purposes by their sophomore year in college (Journal of Addictive Behavior, retrieved 12/3/2013). College age youth have the highest prevalence rate of non-medical use of prescription opioids in the United States (McCabe, 2007; 
SAMHSA, 2009a).The American Journal of Preventive Medicine relates that Drug Poisoning is now the leading cause of injury death in the US, increasing more than 300 percent over the last three decades. Almost 90-percent of poisoning deaths can be attributed to the legal or illegal use of prescription medications (AJPM Nov. 2013).

The Monitoring the Future Studies have looked at the late-child through adolescence to mid-adult ages to monitor risk for the development of a Substance Use Disorder (Johnson et. al (2019); Meich et al (2017). The results from 2018 reference a moderate though steady increase in opioid abuse from 1977 through 1992. They reference a steeper increase from 1992 until 2009, though qualifies this as being consistent with other forms of drug abuse. (Johnson et. al (2019). The sharp increase in opioid medication use/abuse demonstrates a sharp increase in prevalence from 3.3\% to $9.5 \%$ from 1992 until 2004 when it leveled out (Johnson et. al, 2019; Miech et. al 2017). Interestingly the studies show a substantial decline from 2009 through 2018 from $9.2 \%$ to $3.4 \%$, possibly due to national exposure to the dangers of the nonmedical use of prescription opioid medications. To more specifically consider the prevalence of the misuse of opioid pain medications, McCabe (2007) published a study purporting that students who took opioids for other than pain relief had a much greater risk of experiencing three or more drug related problems. He later presented further research reporting that students who take prescription medication for non-medical symptoms are five-times more likely to develop a drug abuse or substance dependence problem (McCabe, 2008). Fifty percent of college students are offered a prescription medication for non-medical purposes by their sophomore year in college (Journal of Addictive Behavior, retrieved 12/3/2013). Similar research suggest that as many as twelve-percent of college students report having misused an opioid in their lifetime. College age youth have the highest prevalence rate of non-medical use of prescription opioids in the United States (McCabe, 2007; SAMHSA, 2009a).

A secondary exploration is to survey the presence of pseudoaddictive behaviors as this can contribute to opioid misuse. The incidence of pseudoaddiction is a challenge throughout the process of pain management. Pseudoaddiction is the development of an addictive behavior that is motivated more by undermanaged pain than recreational intentions (Fishbain, 2003). Pseudoaddictive behaviors may include reactive escalation, seeking medication from multiple physicians for overlapping prescriptions, and illicit behaviors like buying prescription pain medication off the street. A secondary research question will address the incidence of misuse or overuse of prescription and nonprescription medications for pain management due to unrealistic expectation. The unrealistic expectation for pain management associated with prescription and nonprescription pain medication contributes to over use of such medications and the development of pseudoaddictive behaviors. These pseudoaddictive behaviors can, at times, continue over an extended period of time and lead to more destructive behaviors such as substance dependence or more physically dangerous conditions including medically significant damage to the liver and kidneys due to chemical toxicity.

\section{Method}

This study will utilize a survey comprised of a standardized assessment and general demographic information that is randomly offered to college students in a single college population including both On-Campus and On-Line students. Students were invited to participate in the study by email. The survey utilized Google Docs for distribution and categorization of responses. The data was then assessed for frequency variability and validity utilizing the SPSS program. The content of the survey is detailed in Appendix A. The results of this survey were be compiled directly by Dr. Gilbert.

\section{Implications}

By better understanding the potential for the overuse of pain medications and the extent to which unrealistic expectation for pain relief may impact inappropriate use of such medications, improved education efforts may be instituted to improve compliant use of such medications for the purpose of pain management, potentially decreasing the incidence of inappropriate use in the college population. Additionally, some insight may be possible related to the initial overuse or misuse of pain medication contributing to eventual abuse of and dependence upon pain medications.

\section{Limitations}

This study differs slightly by specifically measuring the potential for misuse of opioids in this population rather than the retrospective analysis of previous behaviors. Additional limitations are related to the limited sample size.

\section{Proposed explanations}

The use of opioid pain medications has an inherent risk for misuse, either due to the phenomenon of pseudoaddiction or the temptation for recreational use. The SOAPP-R does not separate these different motivations for misuse/addictive behavior; rather, it is a projective measure of risk based upon response style on the instrument. In relation to design, while the entire student population received the questionnaire, the sampling methodology did not utilize a systematic random sample; as such, the results are not generalizable. The probability sampling can only give information about those who answered the questionnaire. 


\section{Results}

The survey resulted in 134 responses $(\mathrm{N}=132)$, of which $82 \%(\mathrm{n}=110)$ were female, $16.4 \%(\mathrm{~N}=22)$ were male and $1.5 \%$ $(\mathrm{N}=2)$ declined to assign gender. Of those respondents, $12.68 \%(\mathrm{~N}=17)$ fell in the High Risk category on the SSOAP$\mathrm{R}, 44.77 \%(\mathrm{~N}=60)$ fell in the Moderate Risk Category, and 42.53\% ( $\mathrm{N}=57)$ fell in the Low Risk Category.

Looking at each risk category in regards to expectation for pain relief, respondents were asked, "When you take some form of pain medication, do you expect to become pain free?" Of those respondents in the High Risk category, 58.8\% $(\mathrm{N}=10)$ also reported an expectation to be pain free after taking some form of pain medication. Of the Moderate Risk category $78 \%(\mathrm{~N}=47)$ expected to be pain free, while $66.7 \%(\mathrm{~N}=38)$ of the Low Risk category expected to be pain free.

\section{Conclusion}

While there does appear to be an increased risk of opioid abuse in this limited sample of college students, the unrealistic expectation for pain relief associated with the use of some form of pain medication was not shown to be clinically significant. In application, the impact of pseudoaddictive behaviors may not have significantly contributed to increased risk of opioid abuse or dependence in this population sample.

\section{References}

Clark M, Fenech M (2018). Nonmedical Use of Prescription Drugs at University of Malta. https://www.edumt 1_data/assets/p df_file/004/356278/clarkfenech.pdf. Retrieved 3/2/2019.

Fishbain DA (2003) Chronic Opioid Treatment, Addiction and Pseudoaddiction in Patients with Chronic Pain. Addiction, Feb 1, 2003.

Green, MS, Chambers RA (2015). Pseudoaddiction, Fact or Fiction?An Investigation of Medical Literature. Current Addiction Reports, 2015:2(4): 310-317. doi: 10.1007/s40429-015-0047-7

Johnson LD, Miech RA, O’Malley PM, Bachman JG, Schulenberg JS \&

Patrick ME (2019). Monitoring The Future National Survey Results on Drug use 1975-2018: Overview, Key Findings on Adolescent Drug Use. Ann Arber: Institute for Social Research, University of Michigan.http://www.mon itoringthefu ture.org//pressreleases/19drugpr.pdfAccessed 3/2/2019

McCabe SE, Teter CJ, Boyd CJ (2005). Illicit use of Prescription Pain Medications Among College Students. Drug and Alcohol Dependence, 2005. Jan 7, 77(1) 37-47.

MaCabe SE, Veliz P, Boyd C, Schepis T, McCabe V, Schulenbert J (2019). A

Prospective Study of Nonmedical Use of Prescription Opioids During Adolescence and Substance Use Disorder Symptoms in Early Midlife. Drug and Alcohol Dependence, Vol. 193, 1 Jan. 2019, pp. 377-385

McCobe SE, Teter CJ (2007) Drug Use Related Problems Among

Nonmedical Uses of Prescription Stimulants: A Web Based Survey of College Students From a Midwest University. Drug and Alcohol Dependence. 2007. Nov 2:9(1) 69-76. EPub Jul 12.

Malone P (2017). Dealing with the Opioid Epidemic in College Students.

Presented at: The American Academy of Child and Adolescent Psychiatry Annual Meeting: 23-28 Oct, 2017; Washington, DC

Miech r, Schulenberg J, Johnson J, Bachman J, O’Miley P, \& Patrick M

(2017). Monitoring The Future National Adolescent Drug Trends in 2017: Findings Press Release. Ann Arber, MI: Institute for Social Research. The University of Michigan: 2017. http://www.monitoringthefuture.org //pressreleases /17drugpr.pdf. Accessed 3/4/2019

Rossen LM, Khan D, Warner M (2013). Trends and Geographic Patterns in Drug-Poisoning Death Rates in the US., 1999-2009. American Journal of Preventative Medicine, Vol. 45, Issue 6, e19-e25. DEC. 2013.

Substance Abuse and Mental Health Services Administration (2005).Results

from the 2005 national Survey on Drug Use and Health: Mental Health Findings. National Survey on Drug and Health:

Detailed Use History. Rockville, MD: Substance Abuse and Mental Health Services Administration, 2005.

Substance Abuse and Mental Health Services Administration (2009).Results

from the 2009 national Survey on Drug Use and Health: Mental Health Findings. National Survey on Drug and Health: Detailed Use History. Rockville, MD: Substance Abuse and Mental Health Services Administration, 2009.

Substance Abuse and Mental Health Services Administration (2011).Results

from the 2011 national Survey on Drug Use and Health: Mental Health Findings. National Survey on Drug and Health: Detailed Use History. Rockville, MD: Substance Abuse and Mental Health Services Administration, 2011.

Substance Abuse and Mental Health Services Administration (2013).Results 
from the 2013 national Survey on Drug Use and Health: Mental Health Findings. National Survey on Drug and Health: Detailed Use History. Rockville, MD: Substance Abuse and Mental Health Services Administration, 2013. Weissman DE, Haddox JD (1989). Opioid Pseudoaddiction - An IntragenicSyndrome. PAIN 1989, Mar;36(3). 363-6.

\section{Appendix A}

\section{Informed Consent}

Project Name: Risk of Opioid Misuse in a College Population The University of West Alabama

You are invited to participate in a study examining the potential for the abuse of opioid medications in a college population. We hope to gain an understanding of the inherent risks associated in the use of such medications in young adults in college.

Explanation of study: During the study, you will be asked to fill out a survey about how you manage pain and other unpleasant physical symptoms (using both prescribed and Over-The-Counter medications. The entire procedure should take approximately 30 minutes. This study does not involve any more risks than those encountered in everyday life, nor are there any individual benefits associated with taking part in the research. The primary benefit of this research is scientific. The knowledge gained by conducting this study will provide researchers with a better understanding of the potential for opioid abuse in this specific population and potentially will lead to more effective treatment strategies.

Confidentiality of study: Data collected during the course of this study is identified by number, and not by name. Your name, or other identifying information should not be requested at any time during this survey.I am only interested in group results, and any report of these data will involve the reporting of group data.

Compensation: No compensation is offered for taking part in this research, unless otherwise determined by your instructor.

Voluntary Participation: You do not have to take part in this research project if you do not want to. You can stop participating at any time.

If you have any questions or concerns about this research project please contact Dr. James Gilbert at (601) 601-8307 or jgilbert@uwa.edu. If you have questions regarding your rights as a research participant, please contact Mr. Rodney Granec, Office of Sponsored Programs, 205-652-5392 or RGranec @uwa.edu.

You may print this page for you records.

If you consent to participate, please click the "I consent to participate" button. This will serve as your signature:

["I consent to participate" button will be placed here]

["I decline to participate" button will be placed here]

Appendix B - Online Questionnaire

Risk of Opioid Addiction in a College Population

Would you be willing to help us better understand the risk for Opioid Abuse in college students? This study is intended to explore the projected risk of the misuse of this class of medications in college students and whether their attempts to manage pain and discomfort may place them at greater risk for opioid addiction or misuse.

This survey is completely anonymous and voluntary. By participating, you will be contributing to a better understanding of formal and informal pain management in the college population. By clicking the <Continue> button below, you are consenting to participate in this short, completely anonymous and voluntary survey. There is no maintained record of ISP or other manners of tracking participation, so please be as honest in your responses as possible.

Gender

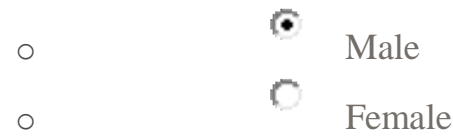

Which best describes how you are enrolled?

\begin{tabular}{ll|l}
$\circ$ & 0 & On-Campus \\
$\circ$ & 0 & On-Line
\end{tabular}

What best describes your class Status? 


\begin{tabular}{ll|l}
$\circ$ & $\mathrm{C}$ & Freshman-Sophomore \\
$\circ$ & $\mathrm{C}$ & Junior-Senior \\
$\circ$ & $\mathrm{C}$ & Graduate \\
$\circ$ & $\mathrm{C}$ & Post-Graduate
\end{tabular}

How often do you experience pain or discomfort that prompts you to take medication for relief?

\begin{tabular}{cc|l}
$\circ$ & Greater than three times per week \\
$\circ$ & 0 & One-to-three times per week \\
$\circ$ & 0 & One time per month \\
$\circ$ & & Less than one time per month
\end{tabular}

Have you been diagnosed with a chronic pain condition by a Licensed Medical Provider?

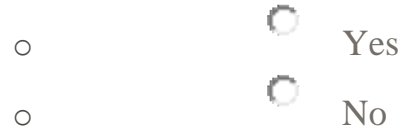

Are you active with a designated Pain Management Clinic or physician?

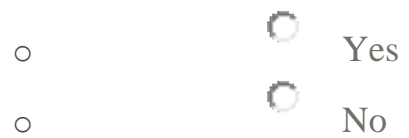

Do you take Over-The-Counter medications (Acetaminophen, Ketoprofen, Ibuprofen, etc) in an attempt to control pain or discomfort?

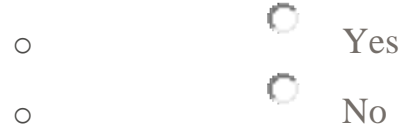

Do you take prescription medication in an attempt to control pain symptoms?

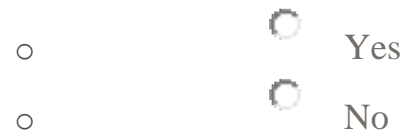

Have you ever taken more than the recommended daily dose, as listed in the directions, of an Over-The-Counter pain medication in an attempt to manage pain or discomfort?

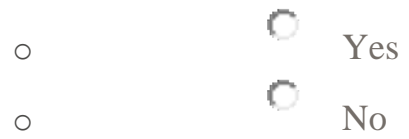

Have you ever taken more than the prescribed dose of a prescription pain medication in an attempt to manage pain or discomfort?

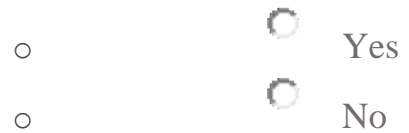

When you take some form of pain medication, do you expect to become pain free?

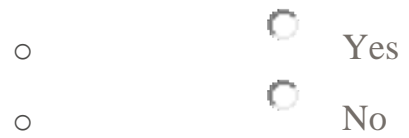

Have you ever consumed Alcoholic Beverages in an attempt to relieve pain symptoms?

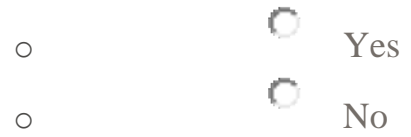

Have you ever consumed more alcohol than intended in an attempt to relieve pain or discomfort?

○

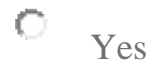




\section{(C) No}

The Following is the SOAPP-R, used by written permission from Inflexxion, Inc. Any reproduction or distribution without written consent of Inflexxion, Inc is strictly prohibited by copyright law. @ 2014 Inflexxion. All Rights Reserved.

How often do you have mood swings?

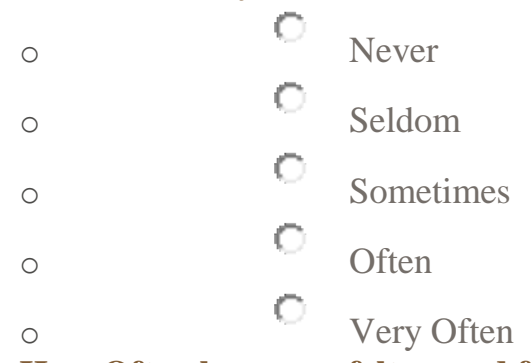

How Often have you felt a need for higher doses of medication to treat your pain?

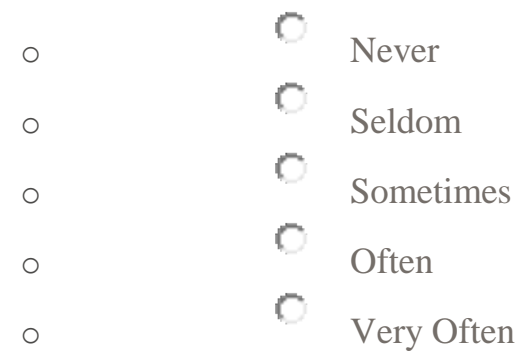

How often have you felt impatient with your doctors?

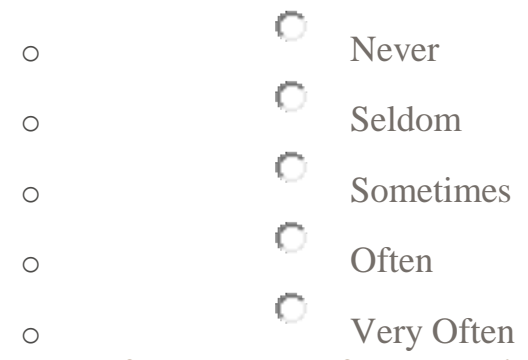

How often have you felt that things are just too overwhelming, that you can't handle them?

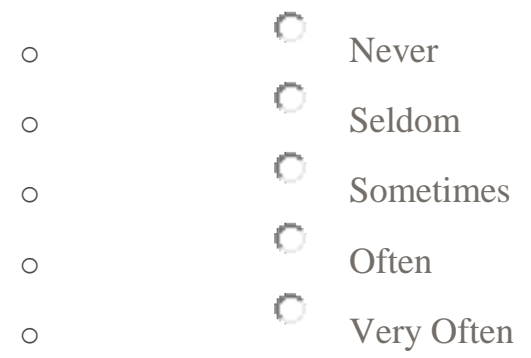

How often is there tension in the home?

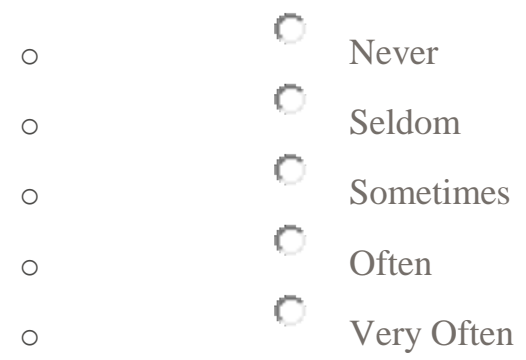

How often have you counted pain pills to see how many are remaining? 


\begin{tabular}{ll|l}
$\circ$ & $\mathrm{C}$ & Seldom \\
$\circ$ & $\mathrm{C}$ & Sometimes \\
$\circ$ & $\mathrm{C}$ & Often \\
$\circ$ & $\mathrm{C}$ & Very Often
\end{tabular}

How often have you been concerned that people will judge you for taking pain medication?

\begin{tabular}{ll|l}
$\circ$ & $\mathrm{C}$ & Never \\
$\circ$ & $\mathrm{C}$ & Seldom \\
\hline & $\mathrm{C}$ & Sometimes \\
$\circ$ & $\mathrm{C}$ & Often \\
$\circ$ & $\mathrm{C}$ & Very Often
\end{tabular}

How often do you feel bored?

\begin{tabular}{ll|l}
$\circ$ & $\mathrm{C}$ & Never \\
$\circ$ & $\mathrm{C}$ & Seldom \\
\hline & $\mathrm{C}$ & Sometimes \\
0 & $\mathrm{C}$ & Often \\
$\circ$ & $\mathrm{C}$ & Very Often \\
\hline
\end{tabular}

How often have you taken more pain medication than you were supposed to?

\begin{tabular}{ll|l}
$\circ$ & $\mathrm{C}$ & Never \\
0 & $\mathrm{C}$ & Seldom \\
0 & $\mathrm{C}$ & Sometimes \\
0 & $\mathrm{C}$ & Often \\
\hline & $\mathrm{C}$ & Very Often
\end{tabular}

How often have you worried about being left alone?

\begin{tabular}{ll|l}
$\circ$ & $\mathrm{C}$ & Never \\
0 & $\mathrm{C}$ & Seldom \\
\hline $\mathrm{C}$ & Sometimes \\
\hline & $\mathrm{C}$ & Often \\
0 & $\mathrm{C}$ & Very Often \\
\hline
\end{tabular}

How often have you felt a craving for medication?

\begin{tabular}{ll|l}
$\circ$ & $\mathrm{C}$ & Never \\
$\circ$ & $\mathrm{C}$ & Seldom \\
\hline & $\mathrm{C}$ & Sometimes \\
0 & $\mathrm{C}$ & Often \\
\hline & $\mathrm{C}$ & Very Often \\
\hline
\end{tabular}

How often have others expressed concern over your use of medication? 


\begin{tabular}{ll|l}
$\circ$ & $\mathrm{C}$ & Seldom \\
$\circ$ & $\mathrm{C}$ & Sometimes \\
$\circ$ & $\mathrm{C}$ & Often \\
$\circ$ & $\mathrm{C}$ & Very Often
\end{tabular}

How often have any of your close friends had a problem with alcohol or drugs?

\begin{tabular}{ll|l}
$\circ$ & $\mathrm{C}$ & Never \\
0 & $\mathrm{C}$ & Seldom \\
0 & $\mathrm{C}$ & Sometimes \\
0 & $\mathrm{C}$ & Often \\
\hline & $\mathrm{C}$ & Very Often \\
\hline
\end{tabular}

How often have others told you that you had a bad temper?

\begin{tabular}{ll|l}
$\circ$ & $\mathrm{C}$ & Never \\
$\circ$ & $\mathrm{C}$ & Seldom \\
\hline & $\mathrm{C}$ & Sometimes \\
$\circ$ & $\mathrm{C}$ & Often \\
$\circ$ & $\mathrm{C}$ & Very Often \\
\hline
\end{tabular}

How often have you felt consumed by the need for get pain medication?

\begin{tabular}{ll|l}
$\circ$ & $\mathrm{C}$ & Never \\
0 & $\mathrm{C}$ & Seldom \\
0 & $\mathrm{C}$ & Sometimes \\
0 & $\mathrm{C}$ & Often \\
\hline & $\mathrm{C}$ & Very Often
\end{tabular}

How often have you run out of pain medication early?

\begin{tabular}{ll|l}
$\circ$ & $\mathrm{C}$ & Never \\
0 & $\mathrm{C}$ & Seldom \\
\hline & $\mathrm{C}$ & Sometimes \\
0 & $\mathrm{C}$ & Often \\
\hline & $\mathrm{C}$ & Very Often \\
\hline
\end{tabular}

How often have others kept you from getting what you deserve?

\begin{tabular}{ll|l}
$\circ$ & $\mathrm{C}$ & Never \\
0 & $\mathrm{C}$ & Seldom \\
\hline & $\mathrm{C}$ & Sometimes \\
0 & $\mathrm{C}$ & Often \\
0 & $\mathrm{C}$ & Very Often
\end{tabular}

How often, in your lifetime, have you had legal problems or been arrested? 


\begin{tabular}{ll|l}
$\circ$ & $\mathrm{C}$ & Seldom \\
$\circ$ & $\mathrm{C}$ & Sometimes \\
$\circ$ & $\mathrm{C}$ & Often \\
$\circ$ & $\mathrm{C}$ & Very Often
\end{tabular}

How often have you attended an AA or NA meeting?

\begin{tabular}{ll|l}
$\circ$ & $C$ & Never \\
$\circ$ & 0 & Seldom \\
0 & 0 & Sometimes \\
0 & 0 & Often \\
0 & 0 & Very Often
\end{tabular}

How often have you been in an argument that was so out of control that someone got hurt?

\begin{tabular}{ll|l}
$\circ$ & $\mathrm{C}$ & Never \\
$\circ$ & $\mathrm{C}$ & Seldom \\
\hline & $\mathrm{C}$ & Sometimes \\
0 & $\mathrm{C}$ & Often \\
$\circ$ & $\mathrm{C}$ & Very Often \\
\hline
\end{tabular}

How often have you been sexually abused?

\begin{tabular}{ll|l}
$\circ$ & $\mathrm{C}$ & Never \\
$\circ$ & $\mathrm{C}$ & Seldom \\
\hline & $\mathrm{C}$ & Sometimes \\
0 & $\mathrm{C}$ & Often \\
\hline & $\mathrm{C}$ & Very Often \\
\hline
\end{tabular}

How often have others suggested that you have a drug or alcohol problem?

\begin{tabular}{ll|l}
$\circ$ & $\mathrm{C}$ & Never \\
\hline & $\mathrm{C}$ & Seldom \\
\hline $\mathrm{C}$ & $\mathrm{C}$ & Sometimes \\
0 & $\mathrm{C}$ & Often \\
0 & $\mathrm{C}$ & Very Often
\end{tabular}

How often have you had to borrow pain medication from your family or friends?

\begin{tabular}{ll|l}
$\circ$ & $\mathrm{C}$ & Never \\
0 & $\mathrm{C}$ & Seldom \\
0 & $\mathrm{C}$ & Sometimes \\
0 & $\mathrm{C}$ & Often \\
\hline & $\mathrm{C}$ & Very Often
\end{tabular}

How often have you been treated for an alcohol or drug problem?

- $\mathrm{C}$ Never 


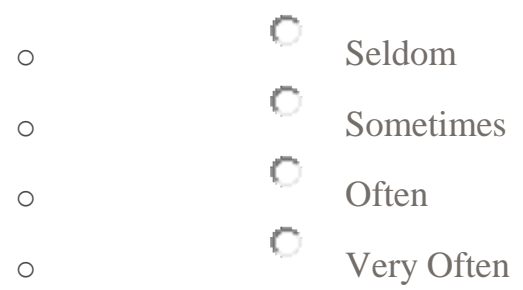

How often have you felt consumed by the need for get pain medication?

\begin{tabular}{ll|l}
$\circ$ & $\mathrm{C}$ & Never \\
$\circ$ & $\mathrm{C}$ & Seldom \\
$\circ$ & $\mathrm{C}$ & Sometimes \\
0 & $\mathrm{C}$ & Often \\
\hline & $\mathrm{C}$ & Very Often \\
\hline
\end{tabular}

How often have others expressed concern over your use of medication?

\begin{tabular}{ll|l}
$\circ$ & 0 & Never \\
$\circ$ & 0 & Seldom \\
0 & 0 & Sometimes \\
\hline 0 & 0 & Often \\
$\circ$ & 0 & Very Often \\
\hline & &
\end{tabular}

\section{Appendix C - Debriefing Form}

Debriefing Form for Participation in a Research Study

The

University

of

West

Alabama

Thank you for your participation in our study! Your participation is greatly appreciated.

Purpose of the Study:

We previously informed you that the purpose of the study was to measure the potential for the misuse of opioid medications in the college population. The goal of our research is to better understand the risk of opioid misuse in this specific population.

If Applicable: We realize that some of the questions asked may have provoked strong emotional reactions. As researchers, we do not provide mental health services and we will not be following up with you after the study. However, we want to provide every participants in this study with a comprehensive and accurate list of clinical resources that are available, should you decide you need assistance at any time. The University of West Alabama provides counseling services for enrolled students, as does most institutions of higher learning. If you are a UWA student, you may contact them directly through the link on your UWA homepage. If you are a student at another institution, you may contact the primary researcher in this study, Dr. James Gilbert, at jgilbert@uwa.edu who will be happy to assist you in finding resources through your institution or through outside agencies.

Confidentiality:

You may decide that you do not want your data used in this research. This can be achieved at any point during the survey process by simply closing the browser window. However, the survey does not log any identifying information about you (name, location, ISP, etc). Therefore, once you have completed the survey, and pressed the <submit> button, your information cannot be specifically identified in order to be deleted. 
If Applicable: Please do not disclose research procedures and/or hypotheses to anyone who might participate in this study in the future as this could affect the results of the study.

Final Report:

If you would like to receive a copy of the final report of this study (or a summary of the findings) when it is completed, please feel free to contact the primary researcher, Dr. James Gilbert, at jgilbert@uwa.edu.

Useful Contact Information:

If you have any questions or concerns regarding this study, its purpose or procedures, or if you have a research-related problem, please feel free to contactthe researcher, Dr. James Gilbert, at 601-693-8307 or by email at jgilbert@uwa.eduIf you have other concerns about this study or would like to speak with someone not directly involved in the research study, you may contact the Chair of the UWA Institutional Review Board,Mr. Rodney Granec, Office of Sponsored Programs, 205-652-5392 or RGranec @uwa.edu.

If you have any questions concerning your rights as a research subject, you may contact The University of West Alabama Intuitional review board through contact Mr. Rodney Granec, Office of Sponsored Programs, 205-652-5392 or RGranec @uwa.edu.

Further Reading(s):

If you would like to learn more about the misuse of opioids in the college population please see the following references:

Fishbain DA (2003) Chronic Opioid Treatment, Addiction and Pseudoaddiction in Patients with Chronic Pain. Addiction, Feb 1, 2003.

McCabe SE, Teter CJ, Boyd CJ (2005). Illicit use of Prescription Pain Medications Among College Students. Drug and Alcohol Dependence, 2005. Jan 7, 77(1) 37-47.

McCobe SE, Teter CJ (2007) Drug Use Related Problems Among Nonmedical Uses of Prescription Stimulants: A Web Based Survey of College Students From a Midwest University. Drug and Alcohol Dependence. 2007. Nov 2:9(1) 69-76. EPub Jul 12.

National Survey on Drug Use and Health (2005).

National Survey on Drugs Use and Health (2011).

National Survey on Drugs Use and Heath (2013).

Rossen LM, Khan D, Warner M (2013). Trends and Geographic Patterns in Drug-Poisoning Death Rates in the US., 1999-2009. American Journal of Preventative Medicine, Vol. 45, Issue 6, e19-e25. DEC. 2013.

Substance Abuse and Mental Health Services Administration (2009). National Survey on Drug and Health: Detailed Use History. 2009.

Substance Abuse and Mental Health Services Administration (2013). National Survey on Drug and Health: Detailed Use History. 2013.

Weissman DE, Haddox JD (1989). Opioid Pseudoaddiction - An Intragenic Syndrome. PAIN 1989, Mar;36(3). 363-6.

***Please keep a copy of this form for your future reference. Once again, thank you for your participation in this study!**** 